\title{
Methodology for Rating of Insurance Portfolio
}

\author{
Alyakina D.P. \\ Khisamova G.F.
}

Kazan Federal University, Institute of Management, Economics and Finance, Kazan, 420008, Kremlevskaya, 18, Russia

\section{Doi:10.5901/mjss.2014.v5n24p137}

\section{Abstract}

The article proposes a methodology for rating of insurance portfolio, which allows the insurance company to ensure the financial stability and solvency. The authors propose the use of three groups of methods to assess the insurance portfolio mathematical and statistical methods, methods of economic analysis, and an analysis of the subjective characteristics of the portfolio. Comprehensive assessment of the insurance portfolio adequately formulate targets of the insurance company

Keywords: Insurance portfolio, Evaluation of quality of insurance portfolio, Methods of evaluation of insurance portfolio, The main index number of insurance portfolio, Insurance reserves

\section{Introduction}

Comprehensive assessment of the insurance portfolio under the contracts allows us to give a forecast of the portfolio, to assess the current and future profitability of insurance operations along the lines of business (type of insurance as a whole or by-products). Assessment of the quality of the insurance portfolio is regarded as one of the key factors in the final rating of the company [1]

A comprehensive assessment of the current insurance portfolio to determine the targets in the medium and longterm period by business lines (products and / or insurance) and to ensure the financial stability and solvency of the insurance company.

\section{Theory}

Analysis of the insurance portfolio usually goes along the following lines:

Tabl 1. The main indicators of the insurance portfolio

\begin{tabular}{|l|l|}
\hline Key indicators & Brief characteristic \\
\hline $\begin{array}{l}\text { Diversification of portfolio } \\
\text { insurance }\end{array}$ & $\begin{array}{l}\text { The high level of portfolio diversification and lack of dependence on large customers ultimately } \\
\text { has a positive effect on the final financial result of insurance operations }\end{array}$ \\
\hline $\begin{array}{l}\text { The stability of the insurance } \\
\text { portfolio }\end{array}$ & $\begin{array}{l}\text { At the level of stability of the insurance portfolio, affect, first of all, a high level of extension of } \\
\text { contracts of insurance. Stable insurance portfolio has a positive effect on the profitability of } \\
\text { insurance operations }\end{array}$ \\
\hline Unprofitability by activity & Group loss ratio reflects the correctness of payment, which is covered by insurance \\
\hline $\begin{array}{l}\text { The technical result is along } \\
\text { the lines of business }\end{array}$ & $\begin{array}{l}\text { Characterizes the ratio of earned premium to the cost of the lines of business, it is necessary } \\
\text { to determine the profitability of the business }\end{array}$ \\
\hline $\begin{array}{l}\text { The relative magnitude of } \\
\text { the risks taken }\end{array}$ & $\begin{array}{l}\text { The relative magnitude of the risks taken by ratio to the size of equity determines the } \\
\text { susceptibility of catastrophic risks }\end{array}$ \\
\hline
\end{tabular}

To assess the portfolio, we propose to use a range of methods, which includes the following groups of methods:

1. Mathematical and statistical methods.

2. Methods of Economic Analysis.

3. Analysis of the subjective characteristics of the portfolio.

Here is a brief description of each group of methods:

1. Mathematical methods imply an adequate assessment of the calculated value of the reserves, and their 
coverage. Sufficient quantity of own funds of the insurance company guarantees its solvency in the presence of several factors - sound insurance reserves and proper investment policy. Let us dwell on the calculation of reserves, their evaluation and coverage. Economic meaning of insurance reserves is the insurer was able to meet its obligations. According to the adopted abroad scheme forming insurance reserves, each kind of commitment that is an insurer cover appropriate kind of insurance reserve. [4]

In particular, life insurance, depending on the terms of existing contracts, formed math reserves, reserves annuities, equity reserves and reserves of participation; for other types of insurance - premiums reserves (Provision for unexpired risks reserve increasing risks) and loss reserves (established but not paid losses, claims lodged, but not established damages; non writing loss). [5]

Insurance reserves in the nature of capital and credit are formed depending on commitments. Since insurance reserves represent liability accounts, the large size of them, provided that adequate reserves liability on insurance contracts, will talk about the solvency insurer if there are at least two conditions: compliance with the proportion amount of own funds; their optimal placement (rational investment policy). [12]

The main purpose of the evaluation of provisions - the adequacy and reasonableness.

Tabl 2. Indicators of insurance reserves

\begin{tabular}{|l|l|l|}
\hline Sufficiency & Coverage & Solvency \\
\hline $\begin{array}{l}\text { The share of insurance premiums } \\
\text { insurance reserves for } \\
\text { risky types of insurance K1 = Insurance } \\
\text { reserves/ netto-premium of risk } \\
\text { insurance * } 100 \% \\
\text { Normal less 100\%. }\end{array}$ & $\begin{array}{l}\text { Coverage level of insurance reserves } \\
\text { own funds } \\
\text { K4 = Own capital / technical insurance } \\
\text { reserves netto *100\% } \\
\text { Normal more 50\%. }\end{array}$ & $\begin{array}{l}\text { The degree of coverage of the insurance } \\
\text { premium own funds and insurance reserves, } \\
\text { the recommended value of the index not less } \\
150 \% \text { K1 = (Own capital + insurance } \\
\text { reserves) / (netto-premium of risk insurance) } \\
\text { * 100\% }\end{array}$ \\
\hline $\begin{array}{l}\text { Coverage level reserve declared, settled } \\
\text { losses cash K2 = Cash flow / reserves } \\
\text { claims * } 100 \% \\
\text { Normal less 100\%. }\end{array}$ & $\begin{array}{l}\text { Adequacy of inflows in the form of } \\
\text { insurance premiums to cover the running } \\
\text { costs of the insurance premiums, the } \\
\text { current cost of doing business, } \\
\text { management, operating expenses } \\
\text { excluding expenses related to investing } \\
\text { activities K5 = (netto-premium of risk } \\
\text { insurance) / costs of the proceedings * }\end{array}$ & $\begin{array}{l}\text { The share of own funds and insurance } \\
\text { reserves in the company's assets K2 = (Own } \\
\text { capital + Insurance reserves) / total capital * } \\
100 \% \\
\text { Normal more 80\%. }\end{array}$ \\
\hline $\begin{array}{l}\text { Normal more 700\%. } \\
\text { Level of cover unearned premium } \\
\text { reserve accounts receivable } \\
\text { (recommended - less 100\%) } \\
\text { K3 = Receivables under insurance, } \\
\text { coinsurance / unearned premium } \\
\text { reserve) * 100\% }\end{array}$ & $\begin{array}{l}\text { Coverage level reserve declared, settled } \\
\text { losses cash K2 = Cash / allowance } \\
\text { claimed, unsettled losses * 100\% } \\
\text { Normal less 100\%. }\end{array}$ & $\begin{array}{l}\text { The share of equity in the obligations of the } \\
\text { company, not related to insurance contracts, } \\
\text { the recommended value of the coefficient of } \\
\text { not less than 100\% } \\
\text { K3 = Own capital / non insurance liabilities * } \\
100 \%\end{array}$ \\
\hline
\end{tabular}

\section{Methods of Economic Analysis}

Analysis of the portfolio on the basis of the static methods in an insurance company on the first few slices.

1.1. The most informative method of calculation - a calculation of underwriting loss. Unprofitability insurance operations - performance indicator of insurance activity insurer for insurance other than life insurance, which is calculated for all types of insurance, or for each type separately. The order of calculation depends on the calculation basis: on underwriting, the calendar year of operation, or by the onset of loss (the insured event). On settlement of the underwriting year is the ratio of insurance payments plus the calculated allowance for losses, including reserves for incurred but not reported claims to accrued (paid or earned) premiums.

On settlement of the calendar year is the ratio, the numerator of which reserves of insurance payments (losses) at the beginning of the calendar year plus insurance payments during the calendar year minus the reserves of insurance payments (loss) at the end of the calendar year in the denominator - earned during the calendar year premium. When calculating on year loss events is the ratio, the numerator of which insurance payments for insured events that occurred during the calendar year, plus insurance reserves for losses incurred during the calendar year and the denominator - the premium earned during the calendar year. 
Loss Ratio $=($ Loss Adjustments / Premiums Earned $)$

Expense Ratio = ( Underwriting Expenses / Net Premiums Written $)$

Combined Ratio $=($ Loss Ratio + Expense Ratio $)[6]$

Often, in order to get a quicker result, the loss ratio is calculated as the ratio of paid losses to the premium received in the underwriting year, allocation of losses for each insurance contract during the term of the insurance contract. Thus, this calculation is made possible only after the contract for a specific period. Therefore, relevant information about a year ago.

2.2. Some companies for rapid assessment of the portfolio in terms of cash flows using a so-called cash settlement loss, which implies a correlation of all paid losses on the portfolio over a given period Casco on all premium received in the same period. This calculation does not allow analysts to review the tariff policy, as it does not identify segments loss.

2.3. Portfolio Assessment on the basis of statistical indicators of the dynamics of the portfolio. By the number of contracts in each period on the collected premiums on these contracts, according to the average of the sum insured portfolio, the average insurance premium. These data are necessary for the subsequent analysis for tariff revision. Also needed are calculations of the average rate for the portfolio. A more analyst on payment of commission is the basis for the discount policy and budget presentation discounts to insurance intermediaries.

The basis of a cost-effective portfolio is a reasonable tariff policy of the correct size net rates. For this vital portfolio assessment on the basis of statistical data on the incidence of accumulated losses, the average size of the damage, determining the highest probability of occurrence of insured events. Separately calculated the average paid loss and the average loss claimed. [13]

Then, based on the statistics of losses projected trend in future periods, which allows you to create policies for the net-rate payment for the portfolio . For example, for a portfolio can be analyzed in the following areas:

Tabl 3. Direction-depth portfolio analysis

\begin{tabular}{|l|l|}
\hline Fields of analysis (tariff factor) & Analysis results \\
\hline Territory into the insurance contract & Reveals territorial differentiation on loss and assess the adequacy of regional coefficients \\
\hline Sales channel & To evaluate the effectiveness of sales channels in order to select the least loss \\
\hline Agent & $\begin{array}{l}\text { As a result of analysis in the context of loss of designers selected designers with the lowest } \\
\text { loss ratio }\end{array}$ \\
\hline The primary conclusion I extension & $\begin{array}{l}\text { Allocated risk population for primary and extended contracts to carry out a comparative } \\
\text { analysis on the key characteristics of profitability }\end{array}$ \\
\hline Brand, model & Reveals the target segments with the highest profitability \\
\hline Insurance contract & $\begin{array}{l}\text { Risk profiling in the context of the insurance sums allows you to select the most interesting } \\
\text { segments of sales }\end{array}$ \\
\hline Insurance summ &
\end{tabular}

These criteria allow the company to make timely adjustments to the tariff policy on motor insurance and thus to achieve break-even insurance operations. Depending on the results of the analysis, selection criteria expand or deepen.

3. Analysis of the subjective characteristics of the portfolio. Reveals the problematic aspects of the insurance portfolio. These characteristics are subjective:

3.1. Level of client companies, which ultimately affects the ratio of clients to the company and the company's image.

3.2. The number and level of complaints to regulatory authorities (in relative terms to the number of contracts), which indirectly indicates the number of dissatisfied customers.

3.3. Level of customer loyalty level prolongation clients complete coverage of each client insurance products.

\section{Results}

The use of only one group of methods does not allow for a full assessment of the insurance portfolio. Initially, in the calculation of loss reserves accounted for the maximum loss ratio, which leads to an overestimation of loss reserves, if not take the case of catastrophic loss of volume. For example, the deviation of the total established reserves against future losses on a massive insurance can reach considerable amounts.

1) Insurance reserves the majority of companies are not fully formed, which in turn affects the amount of investment capital. Can be divided into the causes of the lack of provision for technical and conceptual. 
Specifications related to the division of accrual and cash basis. Conceptual reasons due to weaknesses in the calculation of loss reserves. To evaluate of reservs used primarily statistical methods, most of which is based on triangles - tables of payments in insurance cases occurring over a number of periods. Such statistical methods are many, but they are based on similar assumptions: the development of incurred losses occurring in different time periods, there is a similar manner.

2) It should be noted nonadditivity division business segments, namely: if you break the line of business into several parts and apply to them the same statistical method for estimating the resesrvs, and then add up the results, then we have the estimateentire line of business. However, this estimate is almost never coincides with the estimate considered line of business, received the same statistical method used in this line of business as a whole. In accordance with the practice in most cases the total parts line of business exceeds the estimate of reservs made all along the line of business

3) Lacks depth statistics on line business, then there are statistics available for the loss of an insufficient number of frames. Methods of economic analysis in comparison with other methods provide the most objective view of the portfolio, but does not allow a rapid diagnosis of problematic aspects of the company's image and customer loyalty. In turn, the analysis of the subjective characteristics of the portfolio does not assess the financial and economic indicators of the insurance activities. Only an integrated approach by applying the above techniques to the assessment of the insurance portfolio can more fully characterize the quality of the insurance portfolio and with high precision to give a forecast of its development.

\section{Conclusion}

The use of various alternative methods of analysis in the planning of an insurance organization, break-even analysis and evaluation of the stability of income, representing a coherent system of indicators allows the ultimate in online to get important information to monitor the success factors of financial and economic development of the insurance organization. Balanced insurance portfolio, the possibility of its expansion are factors of competitiveness of the insurer.

Comprehensive assessment of the insurance portfolio allows you to plan targets insurance activities in future periods, and ultimately ensures the financial stability of the insurance operations and solvency of the insurance company

\section{References}

Source: http://www.raexpert.ru/ratings/credits/method/

Peintikainen T. On the solvency of insurance company // Helsinki 2010 pp.236-247

Brown R.L. (1993). Introduction to Ratemaking and Loss Reserving for Property and Casualty Insurance, pp. 66. ACTEX Publications

Source: http://www.activemedia-guide.com/busedu_insure.htm

Basakov M.I. Insurance business in question and answers. Fenix 2001, c.42

Brown RL. (1993). Introduction to Ratemaking and Loss Reserving for Property and Casualty Insurance. ACTEX Publications.

Gvarliani T.E., Balakireva B.U. Cash flow in insurance. 2004, pp. 200-247

England, P.D., Verrall, R.J., Stochastic claims reserving in general insurance, British Actuarial Journal 8/3, 443-518, 2002.

Mack, T., Distribution-free calculation of the standard error of chain ladder reserves estimates, ASTIN Bulletin 23/2, 213-225, 1993.

Merz, M., Wüthrich, M.V., Modelling the claims development result for solvency purposes, CAS E-Forum, Fall 2008, 542-568, 2008.

Taylor, G., Loss Reserving: An Actuarial Perspective, Kluwer, 2000, Boston.

Wüthrich, M.V., Merz, M., Stochastic Claims Reserving Methods in Insurance, Wiley Finance, 2008.

12.Benjamin, B., General Insurance, Heinemann, 1987, London. pp.14-23

Sergei Roldugin, Kristine Andzane, Oleg Zhukov Moscow Motor seminar workshop GenRe 2014 pp.10-25.

Shahov V.V.,Avhlediani U.T. Insurance M.:Unity -Dana, 2011 ISBN 5-238-01970-3 pp.104-132.

Khismatullin B.R. and Kharisova F.I. Insurance as a Way for Reducing the Market Risks Level. World Applied Sciences Journal 31 (6): 1188-1190, 2014. 